\section{Oversiktlig scenariobibliotek for fasilitatorer}

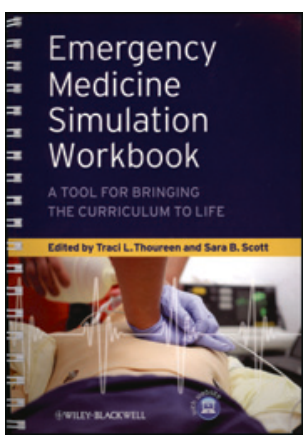

Traci L. Thoureen, Sara B. Scott, red. Emergency medicine simulation workbook

A tool for bringing the curriculum to life. $315 \mathrm{~s}$, ill. Chichester: Wiley-Blackwell, 2013.

Pris GBP 39

ISBN 978-0-4706-5787-4

Simulering som metode gir helsepersonell en unik mulighet til å trene på praktiske ferdigheter og øve på klinisk diagnostikk og behandling, uten at pasienter utsettes for fare. Grundig forberedelse er en forutsetning for en vellykket simulering.

Forfatternes intensjon er å fremme medisinsk simulering ved å gjøre tilgjengelig en samling detaljerte scenariobeskrivelser slik at tid til forberedelse reduseres. Målgruppen er primært fasilitatorer som driver med akuttmedisinsk simulering. Tematisk er boken spesielt tilpasset kravene til kompetanse for leger i spesialiteten «emergency medicine» i USA, men den er like aktuell for indremedisinere, anestesiologer og kirurger som eksponeres for akutt syke pasienter i norske akuttmottak.

Boken er trykt for aktiv bruk i forbindelse med planlegging, gjennomføring og debriefing av simulering. Hele 23 forfattere fra en rekke amerikanske utdanningsinstitusjoner og simuleringssentra har bidratt til innholdet. Den er velskrevet, lettlest og poengtert. Layouten er tiltalende og ryddig, noe som gjør det mulig med raske oppslag.

Et bredt spekter av akuttmedisinske temaer dekkes i 12 av de 13 kapitlene. Hvert kapittel består av en samling av tre-fire realistiske scenariobeskrivelser, som tar utgangspunkt $i$ en kasuistikk basert på en medisinsk eller kirurgisk problemstilling. Alle scenariobeskrivelsene følger samme intuitive mal, der man begynner med å beskrive læringsmålene og presentere en liten sjekkliste over sentrale behandlingstiltak og ferdigheter som forventes av deltakerne. Videre følger en detaljert liste over utstyr og rekvisita som er nødvendig for å gjennomføre simuleringen. Svar på supplerende undersøkelser kan enkelt lastes ned fra bokens egen nettside i form av en powerpointfil. Et flytskjema oppsummerer hvordan den kliniske tilstanden til pasienten utvikler seg. Til slutt i hvert kapittel er det samlet en rekke faglige momenter om symptomer, utredning og behandling av den aktuelle tilstanden, aktuelle litteraturreferanser og tips til spørsmål som fasilitatoren kan stille i debriefingen.

Mange av scenarioene som presenteres, er relativt komplekse og vil i praktisk bruk kreve forenkling. Boken får et stort pluss for kapittel 12 om hvordan man kan simulere håndtering av medisinske feil og kommunikasjonsutfordringer.

Jeg savner imidlertid mer søkelys på ikke-tekniske ferdigheter som beslutningstaking, situasjonsforståelse, ledelse og stressmestring, og hvordan disse ferdighetene kan evalueres. Flere av scenarioene kunne også med fordel vært tilpasset andre omgivelser enn akuttmottaket, for eksempel operasjonsstuen, sengeposten, intensiv- og røntgenavdelingen. Boken kunne gjerne hatt et eget kapittel med forslag til tverrfaglige scenarioer i det prehospitale rom, som har sine helt spesielle utfordringer.

Håkon Bjorheim Abrahamsen

Anestesiavdelingen

Stavanger universitetssjukehus

og

Forskningsavdelingen

Stiftelsen Norsk Luftambulanse

\section{Leseverdig om rasjonalisme og nazisme}

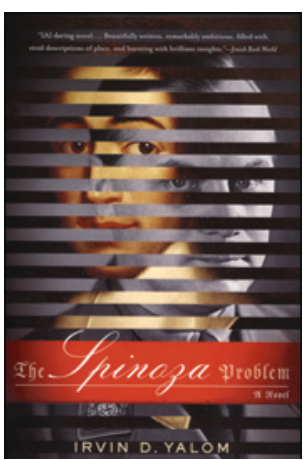

Irvin D. Yalom

The Spinoza problem

A novel. 321 s. New York, NY: Basic Books, 2013. Pris USD 15

ISBN 978-0-465-06185-3

Baruch Spinoza (1632-1677), eller Benedict som han også er kalla, var ein nederlandsk, jødisk filosof som levde på 1600-talet. Han reknes for å vere ein av dei store filosofane innan rasjonalisme. Alfred Rosenberg (1893-1946) blei rekna for å vere ein leiande teolog i utforminga av politikken i nazistpartiet under 2. verdskrig. Han blei dømd til døden under rettsaka i Nürnberg etter krigen og hengd.

Yalom har skrive ein skjønnlitterær roman der han blandar reelle hendingar og fiksjon kring desse to personane. Det er ikkje definert ei særskilt målgruppe, men dei som likar Yalom sine tidlegare romanar, t.d. Lying on the couch, kan like denne også.

Romanen er på engelsk, men finnes også i norsk oversetjing. Språket er lett å følge. Kvart kapittel omhandlar vekselvis Spinoza og Rosenberg, og pendlar såleis fram og tilbake i tid.

Romanen er fengslande. Sjølv om ein veit historisk kva som skjedde med Spinoza og Rosenberg, vekker forfattaren nysgjerrigheita og interessa, så ein blar fort vidare til neste side. Yalom, som er professor i psykiatri, gir eit godt bilete av korleis det kan tenkes at Spinoza og Rosenberg opplevde kvar sine turbulente tider og konflikter. Yalom har gode kunnskapar om begge subjekta, og romanen kan gi ei kort innføring i tenkesetta til desse to mennene, som har påverka historia på kvar sin måte.

Jeanette Bjørke-Bertheussen

Helse Førde 